\title{
A Study on the Reasons for Retirement: A Focus on Age as a Major Factor
}

\author{
Zaihan Mohd Noar \\ Kulliyyah of Science International Islamic University Malaysia
}

\begin{abstract}
This study was carried out to investigate the reasons that influence individuals to plan for retirement. A survey was conducted among employees of the International Islamic University Malaysia in Kuantan. Reasons to retire are almost similar across the globe, given that the basic needs of human beings are similar. There are many studies and literatures that investigate the factors that influence retirement which relates to the socio-economic factor such as retirement age, income, and gender. De Vaney identified that age and income are the important factors that act as a guide to pre-retirees in their retirement planning process. ${ }^{1}$ In this study, attaining the retired age is the main factor that relate to the individual's planning for retirement. Other factors include household income, family and health. The findings of this study are parallel to the other research based on the analysis of the available literature review. Several implications emerge from these empirical findings. First, employees should prepare a proper retirement planning in their life and second, the authorities should provide better care and facilities to retirees.
\end{abstract}

KEYWORDS: retirement planning, financial, savings, age, health, gender

\section{INTRODUCTION}

Many people want to postpone retirement although they have reached old age and continue working due to financial reasons. There is no real definition of "old age" or when a person actually becomes old. However, there is no denying that humans are bound with nature of biological aging process. Due to this aging process, continuous working becomes undesirable. Knowledge workers to a certain extent is able to substitute physical strength with knowledge gained through education and years of experience which is of value to employers and not being sufficiently replaced by the younger age bracket. Those who rely on physical strength in the course of their job will find postponement of retirement age not possible as the older they get, the weaker their physical strength becomes. This group of people also are in the lower income bracket having limited income. While they may be aware of the importance of retirement planning, their limited income is hardly enough to put some aside for the future. Proper retirement planning for workers must therefore not only be the concern of individual worker but also the government to ensure that workers especially the lower income group meet the basic requirement to live a decent life in their retirement years.

Corresponding author

Zaihan Mohd Noar

Kulliyyah of Science

International Islamic University Malaysia

Jalan Sultan Ahmad Shah,

25200 Kuantan,

Pahang, Malaysia

Email: tozaih@yahoo.com
While there are many studies carried out across the globe on retirement, studies in Malaysia on retirement planning is deemed just as important. This is because retirees (age 60 years and above) population in Malaysia is progressively increasing. Women, Family and Community Development Minister Datuk Seri Rohani Abdul Karim said a forecast by the Statistics Department showed that Malaysia's senior citizen population (aged 60 years and above) would rise to 5.6 million by $2035 .^{2}$ This is in fact evidently true in Malaysia where the number of recipients of the Welfare Department's Assistance for the Elderly programme (or Bantuan Orang Tua), was more than 11,000 in 2002, receiving more than $\mathrm{RM} 17$ million. In 2010, the number had multiplied to more than 120,000 people receiving more than $\mathrm{RM} 422.5$ million. $^{3}$ Thus, Malaysia needs to make preparation to face the challenges of an ageing nation. Challenges of an ageing nation include ensuring health care services, financials as well as infrastructure that are senior citizen friendly. This is important as without proper planning a nation could face unhealthy social problems with regards to their old age population for example old age poverty just to name one.

In the human life cycle, on average in the first 25 years of our life, we are dependents to our parents, guardian, etc. When we start work either after finishing secondary school or higher education we earn our own living and support ourselves and our dependents (if any). Then depending on the country we live, like in Malaysia, workers are expected to retire when they reach the retirement age of 60 years old. The next phase of our lives is the retirement phase where our livelihood depend on 
whatever savings that we have accumulated earlier. According to the Malaysia Population Statistics 2013 estimate (Source: Department of Statistics $(1986 ; 1993 ; 2002 ; 2013)$ Peninsula Malaysia only), the average life expectancy of a Malaysian is 72.6 years for male and 77.2 years for female. ${ }^{4}$ This means that on average, a worker has to survive on his savings for the remaining livelihood during the retirement phase. This accounts for $20 \%$ of his life span and $53 \%$ of his independent life. With the high ratio of retirement to working life, it is important to study age as a factor of retirement.

Islam teaches us to do the good and serve the elderly. Giving priority to the elderly in different situations is a token of respect and honour to them. It was narrated that the Prophet (peace and blessings be upon him) said, "Jibreel ordered me to give priority to the elderly".

\subsection{Several Main Reasons for Retirement}

Retiring earlier than planned can be due to a number of reasons. There are many studies and literatures on retirement planning that relates to the socio-economic factor which include retirement age, income, gender etc.

De Vaney identified age and income as the important factors that guide pre-retirees in their retirement planning process. ${ }^{1}$ Mandatory retirement is normally justified by the fact that workers' productivity declines once they reach retirement age; therefore, retiring employees at a certain mandatory age is a way for employers to avoid reduced productivity.

However, there are studies done on productivity of older workers in the workforce. International studies of productivity indicate more variation within age bands than between them. ${ }^{5}$ An extensive literature review by Davies, Matthews and Wong and Warr concluded that there was no clear evidence of a universal age deficit in job performance. ${ }^{5,6}$ Although younger workers have the advantage over their older colleagues in terms of physical strength, older workers may be at a disadvantage than their younger colleagues in jobs that require physical strength, fast reaction time and high levels of visual attention. In many cases other than in these areas, older workers are able to perform at least as well as, or even better than their younger colleagues. Nevertheless, there are evidences that with age, cognitive ability declines, response rates are slower and there are deficits in long -term memory. ${ }^{7}$ This will affect a highly complex, and speed related tasks. Using a variety of strategies, older workers can often very effectively compensate, making their performance comparable to younger workers. ${ }^{8}$

According to Lee et. al (2010), after the year of 2015, increase in the 60 plus population will be greatest in just over half of the world's countries. Thereafter, the increase in the 60 plus population will be the most important change in the population age structure throughout the world. Bartram and Roe emphasised further that "this is expected to increase and will have a huge impact on the dependency ratio: the number of productive working citizens to non-productive (young, disabled, elderly)". ${ }^{9}$

Many governments are seeking to increase workforce participation by older workers and to discourage early retirement. In a study by Society of Actuaries 2011 titled "Working In Retirement" the findings (refer to the Figure 1) show that there is a huge gap between actual age of those who have retired from the primary occupation when compared against the age where pre-retirees are expected to retire. The retirement age for those currently retiring is considerably younger than that at which pre-retirees say they expect to retire. This finding has been consistent in the past few surveys, indicating that the most probable reason for retirement is due to age.

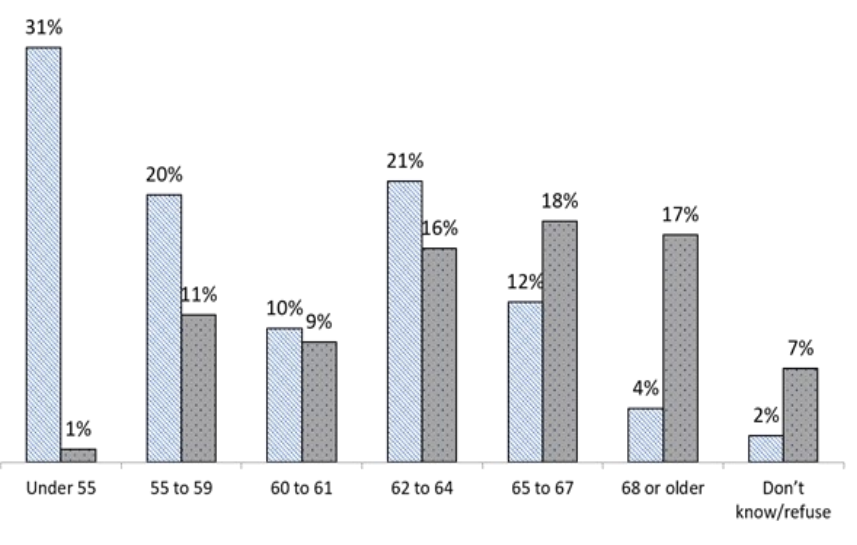

$\square$ Retirees Retired from primary occupation $\square$ Pre-retirees expecting to Retire

Figure 1 : (Source: 2011 Society of Actuaries Key Findings: Working in Retirement)

Question 1: (Retirees) How old were you when you retired or began to retire from your primary occupation? Question 2: (Pre-retirees) At what age do you expect to retire from your primary occupation?

There are many reasons people retire earlier that the mandated retirement age, more so for "voluntary" reasons. Countries with generous early pension provisions might also be the probable reason that triggers pre-retirees to target to retire at an earlier age. The Malaysia Pension Scheme in 1991 allows a public officer to volunteer early retirement on condition that he or she is at the age of forty and has been in service not less than 10 years. Besides that, many other reasons induce early retirement, the most obvious reasons would include tired of commuting, stressful working environment, annoying boss etc. However, probably the most typically tempting reason assumed among female workers would be because they could financially afford to do so. For one, as stated above, the (Another factor that induces retirement is that) 
public sector worker in Malaysia is able to collect pension money much earlier than age 60 years old.

\section{Health as a Reason for Planning to Retire}

A study in New Zealand reported that New Zealanders are enjoying better health status in old age and they have a growing life expectancy. Health status is an important influence of retirement decision and it is ranked first in the Health, Work and Retirement Study by both retired and nonretired groups. ${ }^{10}$

Another study finding from the Merrill Lynch/Age Wave report on Americans' Perspective on New Retirement Realities and the Longevity Bonus, 2013 Merrill Lynch Retirement Study conducted in partnership with Age Wave, (showed that) the reasons for early retirement were:

- 34 percent due to personal health problems

- 27 percent due to accumulated sufficient financial resources to retire

- 24 percent lost their job

- 16 percent wanted to spend more time with family

- 10 percent needed to care for a family member

According to the 2011 Society of Actuaries Key findings: Working in Retirement (refer to Figure 2); while pre-retirees are more likely to give reasons for retirement in relation to finances, retirees tend to say they retired when they did because of health problems or disability (27 percent), because they met their age or years of service requirement (19 percent), or because that is when they stopped working completely (17 percent).

\begin{tabular}{lll}
\hline & $\begin{array}{l}\text { Retirees } \\
(\mathrm{n}=746)\end{array}$ & $\begin{array}{l}\text { Pre- } \\
\text { retirees } \\
(\mathrm{n}=466)\end{array}$ \\
\hline Health Problems/disabled & $27 \%$ & $4 \%$ \\
Met age/years of service & $19 \%$ & $19 \%$ \\
$\begin{array}{l}\text { Stopped working completely } \\
\begin{array}{l}\text { Started receiving } \\
\text { pension/Social security }\end{array}\end{array}$ & $17 \%$ & $18 \%$ \\
$\begin{array}{l}\text { Got tired of working/had } \\
\text { enough }\end{array}$ & $9 \%$ & $20 \%$ \\
$\begin{array}{l}\text { Had enough money to stop } \\
\text { working }\end{array}$ & $8 \%$ & $24 \%$ \\
\hline
\end{tabular}

Figure 2 : (Source: 2011 Society of Actuaries Key Findings: Working in Retirement)

Further findings from this study shows that among retirees who are still working, health problems and disabilities causes them to most frequently cut back on working hours.

In the Malaysian perspective, Chan, Paim, Masud, Hamid, in a study titled "The Future of the Malaysian Older Employees: An Exploratory Study" reported that self-rated health among respondents was quite positive considering $47 \%$ of them $(n=1,090)$ rate their own health as good. A closer inspection in those who ever worked, health status (37\%) was noted to be the highest main reason why the respondents stopped working. Compulsory retirement $(29.2 \%)$ comes as a second reason for retirement. ${ }^{11}$

This suggests that, in general, this group of workers would like to continue with income-generating work for as long as they would like, and for as long as they are able to do but they were held back from achieving their aim due to poor health and compulsory retirement. Poor health problems do influence older workers' labor force participation. It can also affect preferences for work, wage opportunities, and the magnitude of employability. Health may therefore play an important role in the decision to retire. The findings of Chan, Paim, Masud, Hamid found that respondents tend give a high rating on their health condition but actual retirement figures shows that health ranks as one of the top reasons in the decision to retire. ${ }^{11}$

According to the Journal of Occupational Environmental Medicine, the most important reason for workers in deciding to take early retirement is due to poor health besides factors such as high work pressure and low job satisfaction. While people retire due to health reasons, the rising cost of medical care is a concern. In Malaysia, in the past 20 years, there is an increase of $10 \%$ medical cost per year. Although the Malaysian public hospitals provide almost free of charge medical services for citizens, long waiting hours and requirement of patients to buy certain medicines from private pharmacies and queuing for surgery are an issue. Among the private sector workers, the Employees Provident Fund (EPF) is their main source of income to fend for their golden years. However, it is reported that individual savings in the EPF is not enough for the basic needs during retirement, let alone healthcare.

\section{Household Income and Family as the Main Reasons for Planning to Retire}

Income is one of the main factors that have a substantial impact on a person's decision in planning to retire. It is important in the sense that before one retires, a worker must have enough savings or wealth as a preparation to retire. According to Fitri "Income is the most important vehicle to drive people towards a proper retirement planning". ${ }^{12}$ Lee and Law (2004) stated that individuals are motivated to take action to retire as their age and income increases.

To be involved and be able to provide time for family activities may be an incentive for retirement. Having more time to care for family members such as parents or grandparents role may be another reason, in particular for women. ${ }^{13}$ Although recent research has highlighted some of the benefits of combining employment with elder caregiving for 
women $^{14}$, family caregiving needs of a spouse or elderly parent have also been associated with early retirement for women. ${ }^{15}$ This serves as an inducer especially among female workers to retire early and probably focus on the family or children. Results from The Nielsen Global Survey about Aging (2014), show that "Malaysians are the highest among other Southeast Asian consumers who planned or have retired below the age of 60 years (50\%)". The survey also revealed that "after retirement, almost three quarters of the Malaysian respondents would like to focus on spending time with their family while staying physically and mentally fit".

\section{METHODOLOGY}

The quantitative survey was conducted using random sampling technique. An online survey was conducted among employees of the International Islamic University Malaysia Kuantan from various departments. A total of 88 employees responded to the Google form online survey. Findings were tabulated and analyzed using Excel spreadsheet and results are tabulated in charts.

\section{RESULTS}

Figure 3 depicts the main reasons cited by the respondents planning to retire. In this study, several factors were listed down for the respondents to choose their reasons. Respondents however are allowed to choose the main reason as deemed the most important to them as their primary reason to retire.

Age emerged as the most chosen reason (37\%) in planning to retire followed by household income (24\%), followed very closely by family $(22 \%)$ while a very low percentage chose health as the main reason for them to retire.

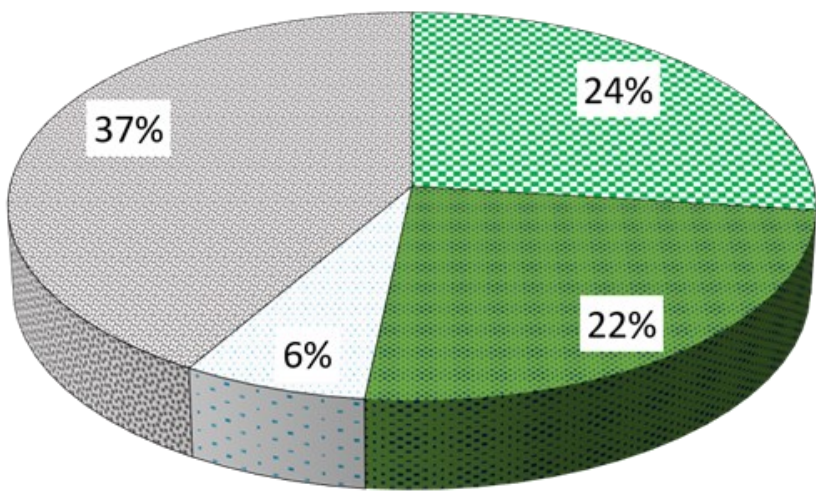

웅 Household Income amily

Health Age

Figure 3 : Reasons for planning for a retirement
Age has appeared as a common reason that people retire. The real retirement timing is sometimes not within our control. There might be incidences that happened along the way that sometimes led to the decision to retire. This might happen sooner than expected in such cases like health disorder, or country economic downturn that led to lay-offs etc. While there are people who choose to retire earlier than the mandatory age especially women, men on the other hand being the family breadwinner often opt a longer working life. However, determining the perfect age to retire is dependable on many other inter-related factors, most often is influenced by income.

The above survey result shows that age is the highest percentage claimed as the main reason for planning to retire. Thirty seven percent of the respondents chose age as their main factor in planning to retire. Age here refers to the mandatory retirement age as stated in their employment contract.

Mandatory retirement age varies according to countries. In Malaysia, on July 1, 2013 the minimum retirement age for most private-sector workers was set at the of age 60 under the Minimum Retirement Age Act 2012. Until now, no statutory minimum age existed, but in practice most private employers set it at the age of 60 for their employees. According to the new law, employer found guilty of requiring an employee to retire before age 60 will be subjected to a fine of RM10, 000. However, the law does not prevent employee from choosing to retire earlier than the age of 60 if the service contract or collective agreement that applies to their job permits an earlier retirement date. Some contracts of employment have a mandatory retirement age (that is, the age at which you must retire), but they also have provisions for earlier retirement generally and/or on grounds of illness.

In general, there is no upper age limit for retirement. The traditional thinking is to replace older workers with younger people but at the same time organizations will lose their most experienced talent as workers retire. The loss of job knowledge will be difficult to replace as the supply of qualified younger people in some areas are limited. In cases like this, employers can develop strategies to continuously take advantage of the knowledge older workers have acquired over the years. Looking at the demographic patterns and declining birth rate, employers may need to retain employees as long as they remain productive. However, retaining older workers come with a higher cost to be incurred by employers i.e. not only do they command higher salaries but it would also mean fewer opportunities for younger workers to advance up the ladder thus resulting in delayed retirements on the career paths of younger workers.

\section{CONCLUSION}

From the findings of this study, we concluded that 
while employees retire because of various reasons, age is the main factor for retirement. In Malaysia, the current retirement age in the public and most private sectors is presumably known to be 60 years old. In general, employees know when they will be retiring as they reach the compulsory retirement age. Those who are financially secured will be ready to retire at this age, while those who are not financially secured will have to continue working; either on contractual basis with their current employers or in a different occupation altogether.

With regard to planning for retirement the following hadith emphasises that a Muslim should have proper planning for their future lives. The Prophet Muhammad s.a.w. advised his ummah in a hadith which says:

"Take benefit of five before five: Your youth before your old age, your health before your sickness, your wealth before your poverty, your free time before you are preoccupied, and your life before your death"

(Narrated by Ibn Abbas and reported by Al Hakim)

\section{REFERENCES}

1. DeVaney SA. Retirement Preparation for Older and Young Baby Boomers: Association for Financial Counselling and Planning Education, 1995. Vol. 6.

2. Daim N. Malaysia to become 'ageing nation' by 2035. New Straits Times. 23 March, 2016.

3. Mazlan M. Time to be mindful for old-age poverty. New Straits Times. 29 April, 2015.

4. Department Of Statistics. Statistics. Department Of Statistics Malaysia. [Online] 2013.

https://www.dosm.gov.my/v1/uploads/files/3 _Time\%20Series/Malaysia\%20Time\%20Series\%20 2013/21Perangkaan_Penduduk.pdf. Accessed November 18, 2018.

5. Warr P.In What Circumstances Does Job Performance Vary with Age. 1993, European Work \& Organizational Psychologist, pp. 237249.

6. Davies DR, Matthews $G$ and Wong CSK. Ageing and Work. Oxford,England : s.n., 1991, C.L Cooper\& I.T Robertson (Eds.): International Review of Industrial and Organizational Psychology, Vol. 6, pp. 149-211.

7. Alpass F and Mortimer R. Ageing Workforces \& Ageing Occupations : A discussion paper. Wellington : s.n., 2007. ISBN 0-478-28087-4.

8. Salthouse TA. The Processing Speed Theory of Adult Ages Differences in Cognition.. 103(3), 1996, Psychological Review, pp. 403-428.

9. Bartram $L$ and Roe B.Dependency ratios : Useful policy-making tools? 4, 2005, Geriatrics \& Gerontology International, Vol. 5, pp. 224228.

10. Davey J.What Influences Retirement Decisions? 33, March, 2008, Social Policy Journal of New Zealand, pp. 110-125.

11. Yin-Fah BC, et al. The Future of The Malaysian Older Employees : An Exploratory Study. 4,
April, 2010, International Journal of Business and Management, Vol. 5, pp. 125-129.

12. Mansor MF, et al. Demographic Factors Associated with Retirement Planning: A Study of Employees in Malaysian Health Sectors. Asian Social Science. 2015, Vol. 11, 13.

13. Millward C.Effects of Gender and Paid Work on Grandparenting. 46, 1997, Family Matter, pp. 18-21.

14. Scharlach AE.Caregiving and Employment : Competing or Complementary Roles? 3, 1 June, 1994, The Gerontologist, Vol. 34, pp. 378-385.

15. Murphy B, et al. Women with multiple roles: the emotional impact of caring for ageing parents. Ageing and Society, Vol. 17, pp. 277291. 